${ }^{1}$ College of Biological Sciences, China Agricultural University, Beijing 100094, People's Republic of China

2 Departamento de Microbiología, Escuela Nacional de Ciencias Biologicas, Instituto Politécnico Nacional, Prol. de Carpio y Plan de Ayala, 11340 México D. F., Mexico

${ }^{3}$ Department of Resource and Environment, Northwest Science and Technology University of Forestry and Agriculture, Yangling, People's Republic of China

\section{Characterization of rhizobia that nodulate legume species of the genus Lespedeza and description of Bradyrhizobium yuanmingense sp. nov.}

\author{
Zhu Yun Yao, ${ }^{1}$ Feng Ling Kan, ${ }^{1}$ En Tao Wang, ${ }^{2}$ Ge Hong Wei ${ }^{1,3}$ \\ and Wen Xin Chen ${ }^{1}$
}

Author for correspondence: Wen Xin Chen. Tel: +86106289 1854. Fax: +861062891055. e-mail: wenxin_chen@263.net

\begin{abstract}
Legume species belonging to the genus Lespedeza are annual or perennial herb or shrub plants that grow in the northern hemisphere. They are known for the formation of root nodules, but little information is available about their microsymbionts. In this study, 58 root-nodule isolates from Lespedeza spp., obtained from China and the USA, were characterized using numerical taxonomic analysis of phenotypic features, SDS-PAGE analysis of whole-cell proteins, DNA-DNA hybridization, 16S rRNA gene sequence analysis and crossnodulation with selected legume species. From the results generated using these approaches, it was concluded that Lespedeza spp. were promiscuous hosts for rhizobia. Four main clusters of bacteria, which included 35 of the strains isolated from Lespedeza spp., were defined upon numerical taxonomic analysis; these groups corresponded to those determined from analyses of protein electrophoretic and DNA-DNA hybridization data. The four clusters were found to define strains belonging to one of four species, Sinorhizobium saheli, Bradyrhizobium japonicum, Bradyrhizobium elkanii or a novel species of the genus Bradyrhizobium. The strains of $B$. japonicum and B. elkanii were all from the USA soil samples, and their representative strains could not nodulate soybean. The seven strains found to represent the novel Bradyrhizobium sp. were from China. These were differentiated from recognized species of the genus Bradyrhizobium by all of the taxonomic methods used here; hence, it is proposed that the novel strains isolated from Lespedeza spp. represent a novel species of the genus Bradyrhizobium, Bradyrhizobium yuanmingense. The type strain of the novel species, CCBAU 10071' (= CFNEB 101'), formed ineffective nodules on Medicago sativa and Melilotus albus but did not nodulate soybean. The other $\mathbf{2 3}$ bacterial strains isolated from Lespedeza spp. were found to form single branches or small groups (two to three strains) that were related to Bradyrhizobium, Mesorhizobium, Rhizobium and Sinorhizobium spp. on the basis of numerical taxonomic analysis, indicating the possibility that other rhizobial species are also associated with Lespedeza spp.
\end{abstract}

Keywords: Lespedeza, Bradyrhizobium, Sinorhizobium, diversity, phylogeny

\section{INTRODUCTION}

Legume species of the genus Lespedeza are annual or perennial wild plants, of which there are known to be

The GenBank accession number for the 16S rRNA gene sequence of Bradyrhizobium yuanmingense CCBAU $10071^{\top}$ is AF193818. around 140 species of herbs or shrubs. Most of these species (125) are native to eastern Asia and about 15 are indigenous to the south-eastern United States (Allen \& Allen, 1981). Most Lespedeza spp. are drought-enduring plants, and are held in high esteem as foliage, green manure crops or honey resources and in preventing soil erosion (Allen \& Allen, 1981). On 
some de-forested hills in north-eastern China, Lespedeza spp. are the main pioneer plants after the trees have been cut; hence, they may be potential plants for re-forestation. Different Lespedeza spp. are used in Chinese herbal medicine, e.g. Lespedeza cyrtobotrya, Lespedeza buergeri, Lespedeza davidii, Lespedeza bicolor and Lespedeza cuneata are used for treating coughs and fevers, and Lespedeza chinensis is used for treating diarrhoea (He, 1993). Clinical tests using constituents (flavonoids or extracts) from Lespedeza spp. have been performed (Campanacci et al., 1965). Research has also been done on the biological degradation of tannins in sericea lespedeza (L. cuneata) by white rot fungi, in an attempt to increase the potential value of $L$. cuneata as a forage crop (Gamble et al., 1996). Previous studies on cross-nodulation (performed between 1917 and 1974; summarized by Allen \& Allen, 1981) indicated that Lespedeza plants belonged to the cowpea miscellany. Marked host specificity relative to the effectiveness of nodulation was also revealed in these previous studies. The perennial Lespedeza spp. showed effective responses to bacterial strains isolated from perennial species, while the annual species had effective responses to the strains isolated from annual species (Allen \& Allen, 1981). The microsymbionts of the leguminous plants of the cowpea miscellany were classified as belonging to the bacterial genus Bradyrhizobium, by using a taxonomic approach (Jordan, 1984). However, the specific taxonomic positions for most of the bacteria associated with the cowpea miscellany were unknown at that time. Since its creation in 1982 (Jordan, 1982), three species have been assigned to the genus Bradyrhizobium: Bradyrhizobium japonicum (Jordan, 1982), Bradyrhizobium elkanii (Kuykendall et al., 1992) and Bradyrhizobium liaoningense (Xu et al., 1995).

So far, about 70 species of Lespedeza have been recorded in China (He, 1993). However, the nodulation of these species and their microsymbionts have not been documented. During a survey of rhizobial resources in the northern parts of China, we obtained a number of rhizobial isolates from a variety of different plants and geographical regions. The characterization of some populations of these isolates according to their geographical origin or host has been done already (Chen et al., 1995; Tan et al., 1999; Wang et al., 1999). Because of the potential values of Lespedeza spp. in agriculture and re-forestation and the uncertain taxonomic position of the rhizobial species associated with them, we decided to characterize the rhizobial strains isolated from these plants using a polyphasic approach. The aims of this research were to check the diversity of these strains and to classify them.

\section{METHODS}

Isolates and strains. Fifty-eight nodule strains isolated from 15 Lespedeza spp. that grow in the USA and in Chinese soils were used in this study (Table 1). The following reference strains were used: B. liaoningense FSI 2062 ${ }^{\mathrm{T}}$ (Xu et al., 1995); B. japonicum USDA $6^{\mathrm{T}}$ (Jordan, 1982); B. japonicum USDA 110 (Gao et al., 1994); B. japonicum B15 (Gao et al., 1994); B. elkanii USDA $76^{\mathrm{T}}$ (Kuykendall et al., 1992); Mesorhizobium loti NZP 2213 ${ }^{\mathrm{T}}$ (Jarvis et al., 1997); Mesorhizobium huakuii CCBAU $2609^{\mathrm{T}}$ (Chen et al., 1991); Mesorhizobium ciceri UPM-Ca $7^{\mathrm{T}}$ (Nour et al., 1994); Mesorhizobium tianshanense A-1BS ${ }^{\mathrm{T}}$ (Chen et al., 1995); Mesorhizobium amorphae ACCC $19665^{\mathrm{T}}$ (Wang et al., 1999); Mesorhizobium plurifarium USDA 4413 (de Lajudie et al., 1998b); Rhizobium leguminosarum USDA 2370 (Jordan, 1984); Rhizobium tropici type B CIAT $899^{\mathrm{T}}$ (MartínezRomero et al., 1991); Rhizobium tropici type A CFN 299 (Martínez-Romero et al., 1991); Rhizobium etli CFN 42 (Segovia et al., 1993); Rhizobium galegae HAMBI $540^{\mathrm{T}}$ (Lindström, 1989); Sinorhizobium meliloti USDA $1002^{\mathrm{T}}$ (Jordan, 1984); Sinorhizobium fredii USDA 205 (Scholla \& Elkan, 1984); Sinorhizobium saheli USDA $4102^{\mathrm{T}}$ (de Lajudie et al., 1994); Sinorhizobium terangae USDA 4101 ${ }^{\mathrm{T}}$ (= ORS $1037^{\mathrm{T}}$ ) (de Lajudie et al., 1994); Escherichia coli DH5 $\alpha$ (Sambrook et al., 1989). Plasmid pUC18 (Sambrook et al., 1989) was also used as a vector for cloning. The Chinese strains were isolated in six provinces or cities in northern China, all within an area of about $2000 \mathrm{~km}$ east to west by $1000 \mathrm{~km}$ north to south. The provinces of Gansu, Shanxi and Shaanxi are located in the Loess Plateau in northwestern China; they have a semi-arid climate and soils that are poor in organic matter. The climate and soils of Beijing and Inner Mongolia are similar to those of Shanxi, but these regions have more rain in the summer. Jilin is a province in north-eastern China; the soils in this region contain more organic matter and water, but the region has very cold winters (below $-20^{\circ} \mathrm{C}$ ). The strains isolated in the USA were obtained from the USDA-ARS Rhizobium Germplasm Resource Collection (United States Department of Agriculture); some of these strains were isolated over half a century ago (Table 1). The symbiotic ability of each novel strain was confirmed by nodulating its original host using the method of Vincent (1970). Of the 15 host species tested, Lespedeza stipulacea and Lespedeza striata are annual herbs; the others are perennial plants.

Phenotypic characterization and numerical taxonomy. Phenotypic features, i.e. the utilization of sole carbon sources and sole nitrogen sources, resistance to antibiotics, tolerance to dyes and chemicals, tolerance to $\mathrm{NaCl}$, temperature and $\mathrm{pH}$ ranges for growth, and some physiological and biochemical reactions, were determined using protocols described previously (Gao et al., 1994). The results of the phenotypic characterization were converted into a binary dataset which was used to estimate the simple matching similarity coefficient (Ssm) of each strain pair and to generate a similarity matrix (Sneath \& Sokal, 1973). The similarity matrix was used for cluster analysis to construct a dendrogram using the unweighted pair group method with averages (UPGMA) (Sneath \& Sokal, 1973). The mean similarity for each strain within a cluster was estimated to present the phenotypic variation in the cluster, as described previously, and the central strain as the representative for the phenotypic cluster was calculated (Sneath \& Sokal, 1973). Generation times were determined in PY medium ( $5 \mathrm{~g}$ peptone of casein, $3 \mathrm{~g}$ yeast extract, $0.6 \mathrm{~g} \mathrm{CaCl}_{2}$; all vales given are per litre of distilled water) by using a spectrophotometric method (Vincent, 1970).

SDS-PAGE of whole-cell proteins. Soluble-protein extraction, SDS-PAGE and scanning of the protein patterns using a Densitometer Extra-Scanner (LKB) were done as described 
Table 1. Bacterial strains used in this study

\begin{tabular}{|c|c|c|}
\hline Strain & Lespedeza host species & $\begin{array}{l}\text { Geographical origin } \\
\text { (year of isolation) }\end{array}$ \\
\hline \multicolumn{3}{|l|}{ Cluster 1 (Sinorhizobium saheli) } \\
\hline $\begin{array}{l}\text { CCBAU 10012, CCBAU 10032, CCBAU 10043, CCBAU } 10063, \\
\text { CCBAU 10171, CCBAU 10091, CCBAU 10113, CCBAU 10143, } \\
\text { CCBAU 10152, CCBAU 10155, CCBAU } 10163\end{array}$ & L. inschanica & Beijing, China (1995) \\
\hline CCBAU 13072, CCBAU 13074 & L. daurica & Jilin, China (1995) \\
\hline CCBAU 13145 & L. tomentosa & Jilin, China (1995) \\
\hline CCBAU 13146 & L. cyrtobotrya & Jilin, China (1995) \\
\hline \multicolumn{3}{|l|}{ Cluster 2 (Bradyrhizobium yuanmingense) } \\
\hline $\begin{array}{l}\text { CCBAU 10011, CCBAU 10030, CCBAU 10031, CCBAU } 10038, \\
\text { CCBAU 10040, CCBAU 10071 }\end{array}$ & L. cuneata & Beijing, China (1995) \\
\hline \multicolumn{3}{|l|}{ Cluster 3 (Bradyrhizobium japonicum) } \\
\hline USDA 3399 & L. juncea var. sericea & USA (unknown) \\
\hline USDA 3638 & L. juncea & OH, USA (1960) \\
\hline USDA 3651 & L. daurica & USA (1960) \\
\hline USDA 3652 & L. daurica & MO, USA (1960) \\
\hline USDA 3654 & L. juncea & USA (1960) \\
\hline \multicolumn{3}{|l|}{ Cluster 4 (Bradyrhizobium elkanii) } \\
\hline USDA 3199 & L. striata & MD, USA (1933) \\
\hline USDA 3203 & L. capitata & OH, USA (1940) \\
\hline USDA 3204 & L. capitata & USA (1932) \\
\hline USDA 3205 & L. stipulacea & NJ, USA (1933) \\
\hline USDA 3211 & L. juncea var. sericea & VA, USA (1914) \\
\hline USDA 3212 & L. juncea var. sericea & TN, USA (1933) \\
\hline USDA 3220 & L. procumbens & SC, USA (1941) \\
\hline USDA 3222 & L. bicolor & SC, USA (1940) \\
\hline \multicolumn{3}{|l|}{ Other Bradyrhizobium strains } \\
\hline CCBAU 10033 & L. cuneata & Beijing, China (1995) \\
\hline USDA 3198 & L. striata & USA (unknown) \\
\hline USDA 3202 & L. capitata & OH, USA (1940) \\
\hline USDA 3208 & L. stipulacea & IN, USA (1938) \\
\hline USDA 3219 & L. juncea var. serpens & SC, USA (1941) \\
\hline \multicolumn{3}{|l|}{ Other fast or moderately growing rhizobial strains } \\
\hline USDA 3197 & L. hirta & OH, USA (1940) \\
\hline USDA 3215 & L. striata & MD, USA (1937) \\
\hline CCBAU 10201, CCBAU 10241, CCBAU 10301 & L. daurica & Beijing, China (1995) \\
\hline CCBAU 73041 & L. formosa & Gansu, China (1995) \\
\hline CCBAU 13008, CCBAU 13132 & L. bicolor & Jilin, China (1995) \\
\hline CCBAU 13143 & L. hydysaroides & Jilin, China (1995) \\
\hline CCBAU 10112, CCBAU 10134 & L. inschanica & Beijing, China (1995) \\
\hline CCBAU 01104 & L. bicolor & Inner Mongolia, China (1995) \\
\hline CCBAU 71055 & L. daurica & Shaanxi, China (1995) \\
\hline CCBAU 71082 & L. bicolor & Shaanxi, China (1995) \\
\hline CCBAU 03208, CCBAU 03216 & L. floribunda & Shanxi, China (1995) \\
\hline CCBAU 03220, CCBAU 03248 & L. daurica & Shanxi, China (1995) \\
\hline
\end{tabular}

previously (Tan et al., 1997). Clustering analysis of the protein patterns was performed as described previously (Tan et al., 1997).

Analyses of 16S rRNA gene sequence data and phylogeny. These were performed only for the representative strain of the novel species, strain CCBAU $10071^{\mathrm{T}}$ (Cluster 2). The complete $16 \mathrm{~S}$ rRNA gene $(\sim 1500 \mathrm{bp})$ was amplified by PCR using the universal forward primer P1 (5'-CGggatcc-
AGFGTTTGATCCTGGTCAGAACGAACGCT-3') and the universal reverse primer P6 (5'-CGggatccTACGGCTACCTTGTTACGACTTCACCCC-3') and a standard protocol. The PCR product was cloned into pUC18, which was then transformed into E. coli DH5 $\alpha$ (Sambrook et al., 1989), as described by Tan et al. (1997). An automated DNA sequencer and primers P1, P2, P3, P4, P5 and P6 (Tan et al., 1997) were used for single-strand sequencing of the cloned $16 \mathrm{~S}$ rRNA gene fragments, after purification of the plasmids. 
The 16S rRNA gene sequence of CCBAU $10071^{\mathrm{T}}$ and the 16S rRNA gene sequences of its related bacterial species (retrieved from GenBank) were aligned by using the program PILEUP in the GCG package (Genetics Computer Group, 1995). Sequence similarities and a phylogenetic tree were obtained using CLUSTAL W (Thompson et al., 1994). The phylogenetic tree constructed was visualized by using TREE VIEW (Page, 1996).

Determination of DNA G $+C$ content and DNA-DNA homology. DNA was prepared by a standard phenol/chloroform extraction (Marmur, 1961). The DNA G + C content of strains was determined using the thermal melting protocol of De Ley (1970), using E. coli K-12 DNA as the standard. DNA-DNA homologies were estimated spectrophotometrically (De Ley et al., 1970). DNA was sheared by passage through a syringe, to generate fragments of $2-5 \times 10^{5} \mathrm{Da}$ in size. Renaturation was performed in $2 \times \mathrm{SSC}$ at the optimum temperature (De Ley et al., 1970).

PCR-based RFLP analysis of 16S rDNA. Primers fD1 and rD1 (Weisburg et al., 1991) and procedures described previously (Wang et al., 1999) were used for amplification of the complete 16S rRNA genes, for digestion of the PCR products with MspI, HinfI, HhaI or Sau3AI, and for separation of the digested fragments in $3.0 \%(\mathrm{w} / \mathrm{v})$ agarose gels.

Cellular plasmid contents. The Eckhardt (1978) procedure modified by Hynes \& McGregor (1990) was used to visualize any plasmids present in the strains.

Cross-inoculation tests. Standard protocols were used (Vincent, 1970). Plants were grown in pots filled with vermiculite moistened with a nitrogen-free plant nutrition solution (Vincent, 1970). Nodulation and nitrogen-fixing abilities of the plants were observed after 1 month. The recommended legume species of Graham et al. (1991), Medicago sativa, Melilotus albus, Vigna unguiculata, Glycyrrhiza uralensis, Glycine max, Phaseolus vulgaris, Pisum sativum, Galega officinalis, Trifolium repens and Leucaena leucocephala, were used as hosts for strain CCBAU $10071^{\mathrm{T}}$, which was isolated from Lespedeza cuneata and was the representative strain of the novel Bradyrhizobium sp. described here. L. cuneata was inoculated with $S$. saheli USDA $4102^{\mathrm{T}}, B$. japonicum USDA $6^{\mathrm{T}}$ and B. elkanii USDA $76^{\mathrm{T}}$. Glycine max was inoculated with USDA 3204 and USDA 3654, representatives of the $B$. japonicum and B. elkanii strains, respectively, isolated from Lespedeza spp.

\section{RESULTS}

\section{Isolation}

The growth rate of and acid/alkali production by each strain were determined on YMA medium (Vincent, 1970) plates during the isolation procedure. Of the 58 strains isolated, 30 from China and two from the USA were fast-growing, acid-producing rhizobia that produced colonies $>2 \mathrm{~mm}$ in diameter after 3-5 days incubation. Eight strains from China and 17 from the USA were slow-growing, alkali-producing bacteria that belonged to the genus Bradyrhizobium, with colonies $\leqslant 1 \mathrm{~mm}$ in diameter after $7-10$ days incubation (Table 1).

\section{Phenotypic characterization and numerical taxonomy}

For all of the strains (including the reference strains), 125 phenotypic features were tested. None of the strains tested used malonate, oxalate, sorbose or Dmethionine as a sole carbon source, and none used DLalanine, L-glutamine or L-threonine as a sole nitrogen source. All of the strains were resistant to $5 \mu \mathrm{g}$ ampicillin $\mathrm{ml}^{-1}, 5 \mu \mathrm{g}$ chloramphenicol $\mathrm{ml}^{-1}, 5 \mu \mathrm{g}$ erythromycin $\mathrm{ml}^{-1}$ and $0.1 \%$ Congo red; they were sensitive to $100 \mu \mathrm{g}$ kanamycin $\mathrm{ml}^{-1}, 300 \mu \mathrm{g}$ erythromycin $\mathrm{ml}^{-1}, 300 \mu \mathrm{g}$ neomycin $\mathrm{ml}^{-1}$ and $0.1 \%$ crystal violet and methylene blue. They were all sensitive to heat treatment at $60{ }^{\circ} \mathrm{C}$ for $10 \mathrm{~min}$, and were catalasepositive. The 105 features found to be variable among the strains were used for the numerical taxonomic analysis. Based on the results of cluster analysis (Fig. 1), the levels of similarity between most of the type strains of recognized species were less than $80 \%$. The exceptions were Mesorhizobium ciceri and Mesorhizobium huakuii, which were separated at the $83 \%$ similarity level. Thirty-five of the 58 strains isolated from Lespedeza spp. belonged to one of four clusters, with around $80 \%$ similarity; other strains formed single branches or small groups (of two to three strains) that consisted of the strains isolated from Lespedeza spp. only or which were related to recognized species (Fig. 1). Some important features of the four clusters are described below.

Cluster 1 consisted of 15 fast-growing strains isolated from four species of Lespedeza ( $L$. inschanica, $L$. daurica, L. tomentosa and L. cyrtobotrya) that grow in the Beijing and Jilin Provinces of China; S. saheli ORS $609^{\mathrm{T}}$ was also found in this cluster. The mean similarities for the strains ranged from $82.0 \%$, in the case of strain CCBAU 13145 , to $88 \cdot 2 \%$, in the case of strain CCBAU 10091 - this latter strain was chosen as the central strain for the cluster. Cluster 1 strains produced colonies that were $>2 \mathrm{~mm}$ in diameter after 2-3 days incubation at $28^{\circ} \mathrm{C}$. All of the strains in this cluster produced acid when grown on YMA plates. They were resistant to $100 \mu \mathrm{g}$ erythromycin $\mathrm{ml}^{-1}$, but sensitive to $50 \mu \mathrm{g}$ kanamycin $\mathrm{ml}^{-1}, 300 \mu \mathrm{g}$ erythromycin $\mathrm{ml}^{-1}$ and $300 \mu \mathrm{g}$ polymyxin $\mathrm{ml}^{-1}$. Growth of Cluster 1 strains was obtained on YMA supplemented with $0 \cdot 1 \%$ Congo red, deoxycholate or nitrite, but not with crystal violet or methylene blue. The strains grew on YMA supplemented with $1 \%(\mathrm{w} / \mathrm{v}) \mathrm{NaCl}$ and at $\mathrm{pH} 5-10$. No nitrate reduction or growth in Luria-Bertani broth was observed for Cluster 1 strains.

The seven strains of Cluster 2 were slow-growing rhizobia that had been isolated from $L$. cuneata found in Beijing. Generation times for strains CCBAU 10011, CCBAU 10038, CCBAU 10040, CCBAU $10071^{\mathrm{T}}$ and CCBAU 10073 were $12 \cdot 5,16 \cdot 0,9 \cdot 5,10 \cdot 2$ and $10 \cdot 2 \mathrm{~h}$, respectively. The mean similarities for the seven strains ranged from $83 \cdot 3$ to $89 \cdot 2 \%$. CCBAU $10071^{\mathrm{T}}$ was designated the representative strain of the cluster. Cluster 2 strains produced single colonies of $1-2 \mathrm{~mm}$ in 


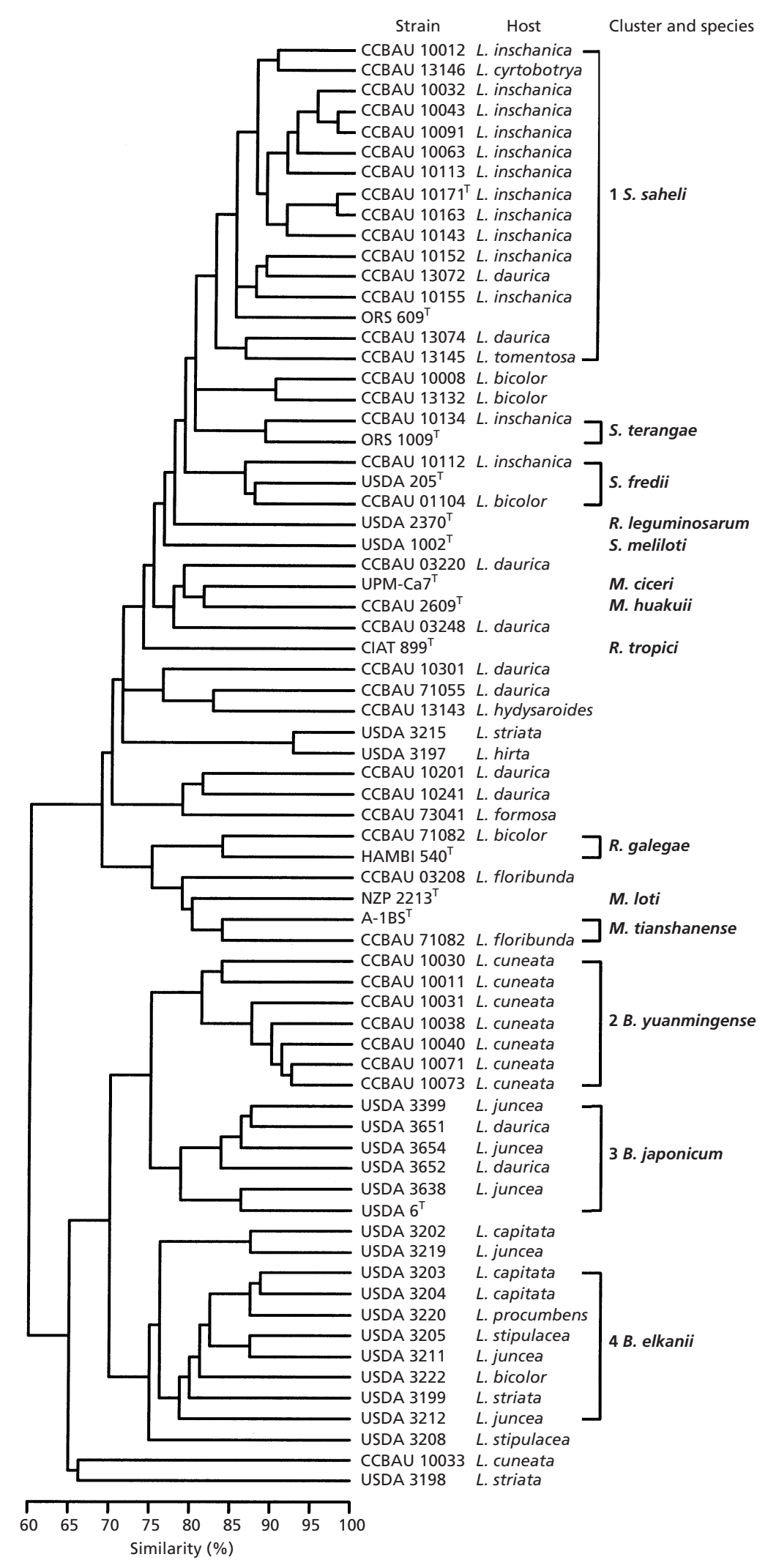

Fig. 1. Dendrogram constructed based on numerical taxonomic analysis using the simple matching similarity coefficient (Ssm) and the UPGMA (Sneath \& Sokal, 1973). Four clusters were recovered among the strains isolated from Lespedeza spp. at the $80 \%$ similarity level.

diameter after 7-10 days incubation, and alkali when grown on YMA or in litmus milk. They were resistant to $300 \mu \mathrm{g}$ polymyxin $\mathrm{ml}^{-1}$, but sensitive to $100 \mu \mathrm{g}$ erythromycin $\mathrm{ml}^{-1}, 1 \% \mathrm{NaCl}(\mathrm{w} / \mathrm{v})$ and $\mathrm{pH} 5$ and 10 . Nitrate was reduced by all seven strains. None of the Cluster 2 strains grew in Luria-Bertani broth. 
Cluster 3 contained five slow-growing strains isolated from $L$. daurica and Lespedeza juncea in the USA; $B$. japonicum USDA $6^{\mathrm{T}}$ was also found in this cluster. The strains within this cluster had mean similarities of $80 \cdot 0-83 \cdot 6 \%$. Strain USDA 3654 was designated the representative strain of the cluster. Cluster 3 strains produced alkali when grown on YMA, and formed single colonies of $<1 \mathrm{~mm}$ in diameter after 7 days incubation on YMA plates. Similar to Cluster 2 strains, Cluster 3 strains were resistant to $300 \mu \mathrm{g}$ polymyxin $\mathrm{ml}^{-1}$ and sensitive to $100 \mu \mathrm{g}$ erythromycin $\mathrm{ml}^{-1}$. No growth was observed in Luria-Bertani broth or on YMA supplemented with $1 \%(\mathrm{w} / \mathrm{v}) \mathrm{NaCl}$ or at $\mathrm{pH} 5$ and 10. All five of the strains reduced nitrate.

Eight slow-growing strains isolated from Lespedeza bicolor, Lespedeza capitata, L. juncea var. sericea, Lespedeza procumbens and L. striata in the USA were grouped in Cluster 4 . They had mean similarities of $80 \cdot 0-84 \cdot 1 \%$. Strain USDA 3204 was designated the representative strain of the cluster. Cluster 4 strains produced single colonies of $<1 \mathrm{~mm}$ in diameter after 1 week incubation on solid medium, and produced alkali when grown on YMA plates. They were resistant to $100 \mu \mathrm{g}$ erythromycin $\mathrm{ml}^{-1}$ and $300 \mu \mathrm{g}$ polymyxin $\mathrm{ml}^{-1}$, and tolerant to $1 \% \mathrm{NaCl}$ and $\mathrm{pH}$ 5. Some of the strains could grow at $\mathrm{pH} 10$. No nitrate reduction or growth in Luria-Bertani broth was observed for the Cluster 4 strains.

Five of the slow-growing, alkali-producing strains isolated from Lespedeza spp. showed 67-77\% similarity with the Bradyrhizobium spp. clusters (Fig. 1), but they could not be included in these clusters. Strains USDA 3202, USDA 3219 and USDA 3208 had similarities of 76-77\% with Cluster 4. Strains CCBAU 10033 and USDA 3198 formed single branches that were divergent from each other and from Clusters 1-4.

The other 17 strains isolated from Lespedeza spp. were fast-growing or moderately growing, acid-producing rhizobia that had closer relationships with Mesorhizobium, Rhizobium or Sinorhizobium spp. than the other strains isolated (Fig. 1). Strain CCBAU 10134, isolated from $L$. inschanica, had $87 \%$ similarity with $S$. terangae USDA $4101^{\mathrm{T}}$. Strains CCBAU 10112 and CCBAU 01104 clustered with $S$. fredii USDA $205^{\mathrm{T}}$ at the $83 \%$ similarity level. Strain CCBAU 03220 shared $80 \%$ similarity with Mesorhizobium ciceri UPM-Ca $7^{\mathrm{T}}$ and Mesorhizobium huakuii CCBAU $2609^{\mathrm{T}}$. Strain CCBAU 71082 was $83 \%$ similar to $R$. galegae HAMBI $540^{\mathrm{T}}$. The remaining 12 strains either formed strain pairs or single branches, which had similarities of $71-80 \%$ with the recognized species.

\section{SDS-PAGE of soluble proteins}

Representative strains and reference strains were selected based on the clustering results of the numerical taxonomic analysis. The grouping of strains based on protein patterns (data not shown) was in general

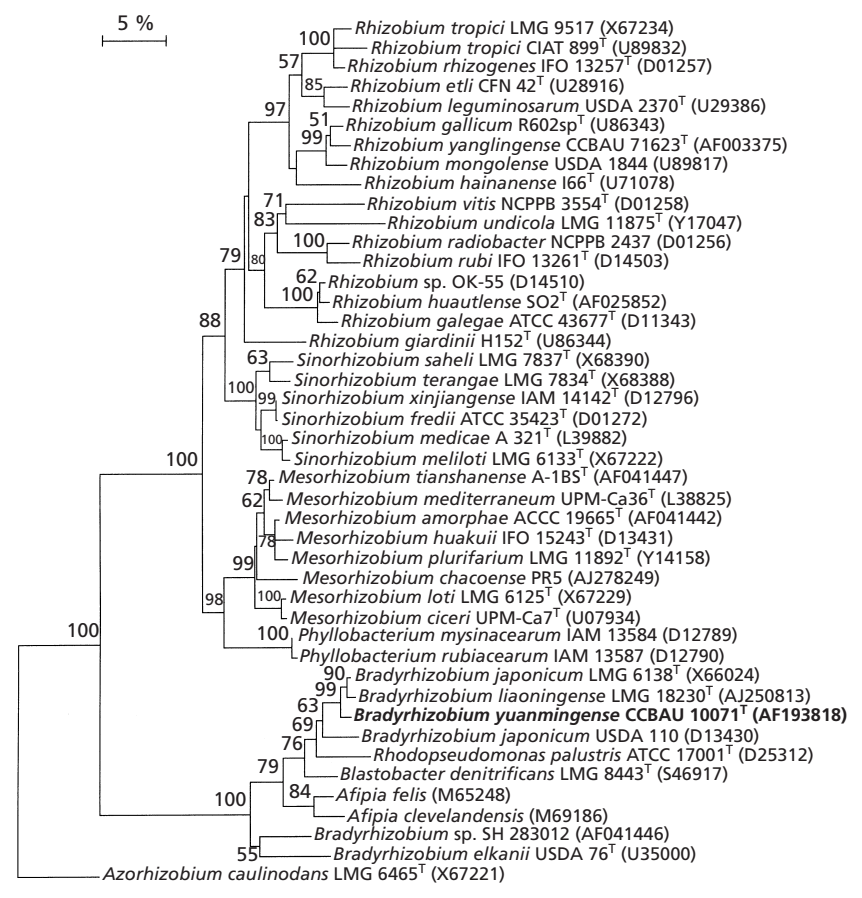

Fig. 2. Dendrogram showing the phylogenetic position of strain CCBAU $10071^{\top}$ (Cluster 2; Fig. 1) with respect to the genus Bradyrhizobium and related genera. 16S rRNA gene sequences were aligned using the PILEUP program in the GCG package (Genetics Computer Group, 1995). CLUSTAL W (Thompson et al., 1994) was used to construct the tree; bootstrap values are shown at the nodes of the tree, and are expressed as a percentage of 1000 replications. Bar, 5 nucleotide substitutions per 100 nucleotides.

agreement with the groupings seen in the numerical taxonomic analysis. $S$. saheli USDA $4102^{\mathrm{T}}$, B. japonicum USDA $6^{\mathrm{T}}$ and B. elkanii USDA $76^{\mathrm{T}}$ clustered with strains of Clusters 1,3 and 4 , respectively. The similarities of the protein patterns ranged from 79 to $94.5 \%$ in Cluster 1 (including $S$. saheli USDA $4102^{\mathrm{T}}$ ), 90.5 to $94 \%$ in Cluster 2, 78 to $90 \%$ in Cluster 3 (including B. japonicum USDA $6^{\mathrm{T}}$ ) and 80 to $93.5 \%$ in Cluster 4 (including $B$. elkanii USDA $76^{\mathrm{T}}$ ). The similarities between strains of the different clusters were $<68 \%$.

\section{$16 \mathrm{~S}$ rRNA gene sequence and phylogenetic analyses}

Two independent 16S rRNA gene clones from strain CCBAU $10071^{\mathrm{T}}$ were sequenced; the sequences from the two clones were identical. The 16S rRNA gene sequence from strain CCBAU $10071^{\mathrm{T}}$ had $99 \cdot 2,98 \cdot 2$, 96.4 and $95.2 \%$ similarity with $16 \mathrm{~S}$ rDNA sequences from $B$. japonicum USDA $6^{\mathrm{T}}$, Bradyrhizobium sp. USDA 110, B. elkanii USDA $76^{\mathrm{T}}$ and Bradyrhizobium sp. (Amorpha) SH 283012 (Wang et al., 1999), respectively. The phylogenetic relationships between the recognized species in the phylogenetic tree we constructed (Fig. 2) were the same as those reported 
Table 2. DNA G $+C$ content and DNA-DNA relatedness values for strains used in this study

Strains: 1, S. saheli CCBAU 10091; 2, B. yuanmingense CCBAU 10071 ${ }^{\mathrm{T}}$; 3, B. japonicum USDA 6 ${ }^{\mathrm{T}}$; 4, B. elkanii USDA 3204; 5 , B. elkanii USDA $76^{\mathrm{T}}$. For each strain, the DNA G $+\mathrm{C}$ content was determined by the thermal denaturation method $\left(T_{\mathrm{m}}\right)$; DNA-DNA relatedness was determined from initial reassociation rates. Data shown represent the mean values of duplicate hybridizations performed using the spectrophotometric method of De Ley et al. (1970). ND, Not determined.

\begin{tabular}{|c|c|c|c|c|c|c|}
\hline \multirow[t]{2}{*}{ Strain } & \multirow[t]{2}{*}{ DNA G $+C$ content $(\mathrm{mol} \%)$} & \multicolumn{5}{|c|}{ DNA-DNA homology (\%) with } \\
\hline & & 1 & 2 & 3 & 4 & 5 \\
\hline \multicolumn{7}{|l|}{ Cluster 1 (S. saheli) } \\
\hline CCBAU 10032 & & $80 \cdot 8$ & & & & \\
\hline CCBAU 10043 & & $91 \cdot 0$ & & & & \\
\hline CCBAU 10063 & & 100 & & & & \\
\hline CCBAU 10171 & & 100 & & & & \\
\hline CCBAU 10091 & & 100 & & & & \\
\hline CCBAU 10113 & & 100 & & & & \\
\hline CCBAU 10143 & & $72 \cdot 2$ & & & & \\
\hline CCBAU 10152 & & 100 & & & & \\
\hline CCBAU 10163 & & $76 \cdot 5$ & & & & \\
\hline CCBAU 13072 & & 100 & & & & \\
\hline CCBAU 13074 & & $92 \cdot 5$ & & & & \\
\hline CCBAU 13145 & & 100 & & & & \\
\hline CCBAU 13146 & & $89 \cdot 6$ & & & & \\
\hline ORS $609^{\mathrm{T}}$ & $64 \cdot 1$ & $89 \cdot 6$ & & & & \\
\hline \multicolumn{7}{|l|}{ Cluster 2 (B. yuanmingense) } \\
\hline CCBAU 10011 & $62 \cdot 4$ & & $72 \cdot 6$ & $10 \cdot 0$ & & \\
\hline CCBAU 10030 & $62 \cdot 2$ & & $75 \cdot 4$ & & & \\
\hline CCBAU 10031 & $64 \cdot 1$ & & $72 \cdot 8$ & & & \\
\hline CCBAU 10038 & $62 \cdot 4$ & & $81 \cdot 0$ & $47 \cdot 8$ & & $42 \cdot 7$ \\
\hline CCBAU 10040 & $63 \cdot 1$ & & $90 \cdot 2$ & $46 \cdot 2$ & & $32 \cdot 3$ \\
\hline CCBAU $10071^{\mathrm{T}}$ & $63 \cdot 0$ & & 100 & & & \\
\hline CCBAU 10073 & $61 \cdot 8$ & & $90 \cdot 6$ & $15 \cdot 8$ & & $11 \cdot 4$ \\
\hline \multicolumn{7}{|l|}{ Cluster 3 (B. japonicum) } \\
\hline USDA 3399 & $62 \cdot 0$ & & & $88 \cdot 6$ & & \\
\hline USDA 3638 & $63 \cdot 9$ & & & $87 \cdot 0$ & & \\
\hline USDA 3651 & $63 \cdot 7$ & & & $72 \cdot 0$ & & \\
\hline USDA 3652 & $62 \cdot 2$ & & & $71 \cdot 4$ & & \\
\hline USDA 3654 & $61 \cdot 8$ & & & $79 \cdot 8$ & & \\
\hline USDA $6^{\mathrm{T}}$ & $63 \cdot 3$ & & $29 \cdot 8$ & 100 & 0 & \\
\hline $\mathrm{B} 15$ & ND & & $23 \cdot 9$ & & & \\
\hline USDA 110 & ND & & $45 \cdot 2$ & & & \\
\hline \multicolumn{7}{|l|}{ Cluster 4 (B. elkanii) } \\
\hline USDA 3203 & $63 \cdot 8$ & & & & $94 \cdot 5$ & \\
\hline USDA 3204 & $63 \cdot 9$ & & & & 100 & \\
\hline USDA 3205 & $64 \cdot 5$ & & & & $78 \cdot 0$ & \\
\hline USDA 3211 & $63 \cdot 9$ & & & & $79 \cdot 6$ & \\
\hline USDA 3212 & $62 \cdot 8$ & & & & 100 & \\
\hline USDA 3220 & $62 \cdot 9$ & & & & $86 \cdot 6$ & \\
\hline USDA 3222 & $63 \cdot 9$ & & & & $72 \cdot 0$ & \\
\hline USDA 3199 & $62 \cdot 1$ & & & & $80 \cdot 3$ & \\
\hline USDA $76^{\mathrm{T}}$ & $63 \cdot 9$ & & $25 \cdot 3 \pm 16 \cdot 8$ & & $91 \cdot 1$ & \\
\hline B. liaoningense SFI $2032^{\mathrm{T}}$ & & & $17 \cdot 3$ & & & \\
\hline
\end{tabular}

previously (e.g. Wang et al., 1999; Willems \& Collins, 1993; Young \& Haukka, 1996). Species of the genera Mesorhizobium (Jarvis et al., 1997) and Sinorhizobium (Chen et al., 1988; de Lajudie et al., 1994) clustered in two monophyletic groups that were distinct from other genera. The remaining fast-growing, acid-producing bacteria clustered in the genus Rhizobium (Young et al., 2001) [formerly comprising the genera Allorhizo- 
Table 3. Characteristics useful for distinguishing B. yuanmingense from related species

Strains: 1, B. yuanmingense (Cluster 2, $n=7$ ); 2, B. elkanii (Cluster 4, $n=8$ ); 3, B. japonicum (Cluster 3, $n=6) ; 4$, B. liaoningense. NR, Not reported; ND, not done. Data from this study for B. yuanmingense, B. elkanii and B. japonicum and from Xu et al. (1995) for B. liaoningense. -, $>95 \%$ isolates negative;,$+>95 \%$ isolates positive; $\mathrm{d}, 5-95 \%$ isolates positive.

\begin{tabular}{|c|c|c|c|c|}
\hline Characteristic & 1 & 2 & 3 & 4 \\
\hline \multicolumn{5}{|l|}{ Carbon sources used: } \\
\hline D-Fructose & - & + & - & \pm \\
\hline Inositol & - & + & + & - \\
\hline Lactose & - & \pm & + & - \\
\hline Maltose/sucrose & \pm & + & + & - \\
\hline \multicolumn{5}{|l|}{ Nitrogen sources used: } \\
\hline $\mathrm{L}(+)$-Aspartic acid & - & + & + & + \\
\hline Glycine & - & + & + & NR \\
\hline \multicolumn{5}{|l|}{ Resistant to: } \\
\hline Erythromycin $\left(100 \mu \mathrm{g} \mathrm{ml}^{-1}\right)$ & - & + & - & - \\
\hline Polymyxin $\left(300 \mu \mathrm{g} \mathrm{ml}^{-1}\right)$ & + & + & - & NR \\
\hline $0 \cdot 1 \%$ Methyl green/deoxycholate & - & + & - & NR \\
\hline $1 \cdot 0 \% \mathrm{NaCl}$ & - & + & + & - \\
\hline Growth at $\mathrm{pH} 5 \cdot 0$ & - & + & - & NR \\
\hline Growth at $\mathrm{pH} 10 \cdot 0$ & - & \pm & - & - \\
\hline Nitrate reduction & + & - & + & NR \\
\hline Colony size after $7-10$ days incubation (mm) & $1 \cdot 0-2 \cdot 0$ & $1 \cdot 0$ & $1 \cdot 0$ & $0 \cdot 2-1 \cdot 0$ \\
\hline Generation time $(\mathrm{h})$ & $9 \cdot 5-16 \cdot 0$ & $>6$ & $>6$ & $16 \cdot 4-39 \cdot 6$ \\
\hline $\mathrm{G}+\mathrm{C}$ content of DNA $(\mathrm{mol} \%)$ & $62-64$ & $62-64$ & $61-65$ & $60-64$ \\
\hline Soybean-nodulating & - & d & d & + \\
\hline L. cuneata-nodulating & + & + & + & ND \\
\hline 16S rRNA gene PCR-RFLP pattern & QMHE* $^{*}$ & PLIE & OKHE & ND \\
\hline
\end{tabular}

* Four letter codes were given to each cluster to represent the restriction patterns produced upon digestion of the amplified 16S rDNA with MspI, HinfI, HhaI and Sau3AI, respectively. For each enzyme, the different letters represent the different restriction patterns produced (not shown).

bium (de Lajudie et al., 1998a), Agrobacterium and Rhizobium (Jordan, 1984)] (Fig. 2). Strain CCBAU $10071^{\mathrm{T}}$, representing Cluster 2, was closely related to B. japonicum and B. liaoningense.

\section{DNA G $+C$ content and DNA-DNA relatedness determinations}

Results of these analyses are shown in Table 2. The DNA $\mathrm{G}+\mathrm{C}$ contents of the Bradyrhizobium strains ranged from 61.8 to $64.5 \mathrm{~mol} \%$, which is within the range for recognized members of the genus $\mathrm{Bra}$ dyrhizobium. The DNA-DNA homology values seen among strains within each of the four clusters were higher than $70 \%$, indicating that Clusters 1-4 represented four distinct genomic species (Graham et al., 1991; Wayne et al., 1987). The mean DNA-DNA homology values were $92 \cdot 3,83 \cdot 2,83 \cdot 1$ and $86.9 \%$ among the strains within Clusters 1, 2, 3 and 4 , respectively. Clusters 1,3 and 4 were identified as $S$. saheli, B. japonicum and B. elkanii, respectively, due to the DNA homology values seen between the representative strains of the clusters and the type strains of the aforementioned species $(89 \cdot 6,100$ and $91 \cdot 1 \%$, respectively). DNA-DNA homology values between the representative strains of Cluster 2 and the reference strains of B. japonicum and B. elkanii ranged from 10 to $47 \cdot 8 \%$.

\section{RFLP analysis of 16S rDNA}

The RFLP patterns produced for the 16S rDNA from the Cluster 2 strains CCBAU 10011, CCBAU 10031, CCBAU 10038, CCBAU 10040, CCBAU $10071^{\mathrm{T}}$ and CCBAU 10073 were identical. Digestion of the $16 \mathrm{~S}$ rDNA of B. japonicum, B. elkanii and Cluster 2 strains with Sau3AI produced identical patterns. Upon digestion of the 16S rDNA from strains of Clusters 1-4, HhaI, MspI and HinfI produced distinctive patterns for the strains of the different clusters. The 16S rDNA from Cluster 2 strains and $B$. japonicum USDA $6^{\mathrm{T}}$ produced the same patterns when digested with Sau3AI or HhaI, but 1-2 bands differed between them in the MspI- or HinfI-digested PCR products. Four letter codes were given to each of the clusters, which represented the patterns produced upon digestion of the 16S rDNA with each of the four different endonucleases (Table 3; patterns not shown). For each 
enzyme, the different letters refer to the different patterns produced.

\section{Determination of cellular plasmid content}

Six strains from Cluster 2 were checked; no plasmids were observed from strains CCBAU 10011, CCBAU 10031, CCBAU 10038, CCBAU 10040, CCBAU $10071^{\mathrm{T}}$ and CCBAU 10073.

\section{Cross-inoculation tests}

Strain CCBAU $10071^{\mathrm{T}}$, representing Cluster 2, nodulated $V$. unguiculata and Glycyrrhiza uralensis, but it did not nodulate Glycine max, Phaseolus vulgaris, Pisum sativum, Galega officinalis, T. repens or Leucaena leucocephala. S. saheli USDA $4102^{\mathrm{T}}, B$. japonicum USDA $6^{\mathrm{T}}$ and $B$. elkanii USDA $76^{\mathrm{T}}$ nodulated Lespedeza cuneata. Two other strains isolated from Lespedeza spp., USDA 3204 (Cluster 4) and USDA 3654 (Cluster 3), did not nodulate Glycine max.

\section{DISCUSSION}

The diversity and classification of rhizobial species associated with Lespedeza spp. have not been investigated systematically. In this study, we characterized rhizobial strains isolated from Lespedeza spp. using a polyphasic approach, which included numerical taxonomic analysis, SDS-PAGE analysis of soluble proteins, DNA-DNA hybridization analysis, 16S rRNA gene sequence analyses and nodulation tests with selected host legumes. The results obtained from the different methods used were in general agreement, and four clusters were recognized among the strains on the basis of these results. Besides the four clusters, some single strain or small groups of (two to three) strains were also identified. Some of the strains studied were distinctive from all the type or reference strains used here for recognized species, while others had more than $80 \%$ phenotypic similarity, as determined by numerical taxonomical analysis, to $B$. japonicum, $S$. saheli, S. terangae, S. fredii, R. galegae or Mesorhizobium tianshanense. These results indicate that Lespedeza spp. are associated with a number of different species belonging to the genera Bradyrhizobium, Rhizobium, Sinorhizobium and Mesorhizobium; however, the single strain branches and small groups of strains were not classified in this study. Therefore, Lespedeza spp. are non-selective hosts for the microsymbionts described here.

Bradyrhizobium strains were the predominant microsymbionts, nodulating Lespedeza spp. from the USA soils (Table 1; Fig. 1). Most of the American strains grouped within Clusters 3 and 4 and were identified as $B$. japonicum and B. elkanii, respectively, on the basis of the results from the different analyses performed. Only four of the American Bradyrhizobium strains did not belong to these two clusters. The Lespedezanodulating strains B. japonicum USDA 3204 and $B$. elkanii USDA 3399 did not nodulate soybean, but the soybean-derived strains $B$. japonicum $\mathrm{USDA} 6^{\mathrm{T}}$ and $B$. elkanii USDA $76^{\mathrm{T}}$ formed nodules on L. cuneata. These results may imply the existence of biovars within Bradyrhizobium spp., but further data regarding the host ranges of the different strains are needed before biovars can be described. It has been reported that the host ranges of Bradyrhizobium spp. are rather complicated. Strains isolated from a wide range of hosts in China (Chen et al., 1991; Gao et al., 1994) have been classified as B. japonicum.

Fast-growing, acid-producing rhizobial species were isolated mainly from Chinese soils associated with nine Lespedeza spp. (Table 1; Fig. 1). Most of these strains grouped in Cluster 1 (S. saheli). S. saheli was originally described for strains nodulating Sesbania spp. in Africa (de Lajudie et al., 1994). The identification of Cluster 1 strains as Sinorhizobium saheli indicated a wide distribution of this bacterium, and added to it new hosts native to the temperate regions of China. The nodulation observed upon inoculation of L. cuneata with the type strain of $S$. saheli demonstrated that the strains isolated from Sesbania spp. and the strains isolated from Lespedeza spp. represent a cross-nodulating group of bacteria. It is interesting that species of Sesbania and Lespedeza can share their microsymbionts, since these two groups of plants have geographical origins and habitats that are very different from each other. In this case, it appears that the symbiotic determinants of the plants may not relate to the phylogeny of the legume species.

Based on our results, geographical restrictions exist for the different rhizobial species that nodulate Lespedeza spp. Although L. bicolor and L. daurica are found in the USA and China, they nodulate with fast-growing, acid-producing rhizobia in Chinese soils and with Bradyrhizobium spp. in American soils. The differences between the USA strains and the Chinese strains might indicate a geographical isolation for these rhizobial populations. In other words, there may be a lack of natural transmission of these rhizobial species between China and the USA. Strains associated with $L$. inschanica were from China and were identified mainly as Sinorhizobium saheli, but two strains grouped with $S$. terangae and $S$. fredii (Fig. 1). L. juncea was found to nodulate with both $B$. elkanii and B. japonicum in the American soils. Although only strains of Bradyrhizobium spp. were isolated from $L$. juncea and $L$. cuneata and strains of Sinorhizobium spp. were the dominant organisms isolated from $L$. inschanica, complex relationships should be expected between the Lespedeza spp. and rhizobial species when more rhizobial strains are investigated.

Diverse Bradyrhizobium populations and many novel groups or lineages belonging to this genus have been reported, including strains isolated from peanut (van Rossum et al., 1995), shrubby legumes (Lafay \& Burdon, 1998), Acacia albida (Dupuy et al., 1994), Aeschynomene spp. (van Berkum et al., 1995; Ladha \& 
So, 1994; So et al., 1994) and Lupinus spp. (Barrera et al., 1997). These reports indicated that novel taxa should be described for these slow-growing, alkaliproducing rhizobia. In this study, Bradyrhizobium strains isolated from L. cuneata growing in Beijing formed a unique group (Cluster 2) based upon the results of numerical taxonomic, SDS-PAGE, $16 \mathrm{~S}$ rDNA RFLP and DNA-DNA hybridization analyses. The high 16S rRNA gene sequence similarity between strain CCBAU $10071^{\mathrm{T}}$ (the representative strain of Cluster 2) and B. japonicum LMG $6138^{\mathrm{T}}$ (Fig. 2) indicated that Cluster 2 represented a lineage within the genus Bradyrhizobium.

We have noticed that the criterion of $70 \%$ DNA-DNA homology as the cut-off value for strains of the same species has been heavily criticized (Ward, 1998); strains showing DNA-DNA homology values of much less than $70 \%$ have been included in some single species, e.g. R. tropici type A and type B (MartínezRomero et al., 1991), Mesorhizobium plurifarium (de Lajudie et al., 1998b) and R. mongolense (van Berkum et al., 1998). These cases offer examples where the definition of a species was not based solely on DNA-DNA homology data, but also on phenotypic distinctiveness and results from other genetic analyses. In this study, strains within Clusters 1, 2, 3 and 4 had DNA-DNA homology values of more than $72 \cdot 2,72 \cdot 6$, 71.4 and $72.0 \%$, respectively. Although DNA-DNA homology values of up to $47.8 \%$ were obtained among the different clusters, there was a big gap between the homologies within a genomic group and among different groups. Therefore, it is clear from our results that Cluster 2 represents a distinct genomic species that is different from B. japonicum, B. liaoningense and B. elkanii. Since the strains within Cluster 2 could be distinguished from the three recognized members of the genus Bradyrhizobium on the basis of phenotypic features, SDS-PAGE analysis of proteins and RFLP analysis of 16S rDNA, we propose that the strains within this cluster represent a novel species of the genus Bradyrhizobium, Bradyrhizobium yuanmingense. Features useful in distinguishing this novel species from other Bradyrhizobium spp. can be found in Table 3; another unique feature of this novel species is that it can form ineffective nodules on Medicago sativa and Melilotus albus, but not on soybean.

\section{Description of Bradyrhizobium yuanmingense sp. nov.}

Bradyrhizobium yuanmingense (yu.an.ming.en'se. N.L. neut. adj. yuanmingense referring to the royal garden Yuanmingyuan in Beijing, China, from where the bacterium was isolated).

Cell morphology is characteristic for the genus. Colonies $<1.0 \mathrm{~mm}$ in diameter after 7 days incubation at $28^{\circ} \mathrm{C}$. Produces alkali on YMA. Generation time is 9.5-16 h in PY broth. Optimum growth temperature is between 25 and $30^{\circ} \mathrm{C}$; no growth at 10 or $40^{\circ} \mathrm{C}$.
Optimum growth $\mathrm{pH}$ is between 6.5 and 7.5 ; no growth at $\mathrm{pH} 5.0$ or 10.0 . Sensitive to $1.0 \%(\mathrm{w} / \mathrm{v}) \mathrm{NaCl}$ in YMA. Reduces nitrate. Uses mannitol, pyruvate and xylose, but not D-ribose, sorbose, starch, D-arginine, glycine or L-methionine as sole carbon source. Nitrate, DL-alanine, L-glutamine, L-isoleucine, L-threonine and hypoxanthine are utilized as sole nitrogen source. Sensitive to treatment at $60{ }^{\circ} \mathrm{C}$. Catalase-positive and L-phenylalaninase-negative. Does not produce 3-ketolactose. Symbiotic genes are chromosomal-borne; no plasmids observed. Other characteristics of the species can be found in Table 3. Isolated from L. cuneata, but also nodulates $V$. unguiculata and Glycyrrhiza uralensis. DNA $\mathrm{G}+\mathrm{C}$ content is $61 \cdot 8-64 \cdot 1 \mathrm{~mol} \%\left(T_{\mathrm{m}}\right)$. The type strain of Bradyrhizobium yuanmingense is CCBAU $10071^{\mathrm{T}}\left(=\right.$ CFNEB $\left.101^{\mathrm{T}}\right)$; generation time of the type strain is $10 \cdot 2 \mathrm{~h}$ and its DNA G $+\mathrm{C}$ content is $63.0 \mathrm{~mol} \%\left(T_{\mathrm{m}}\right)$.

\section{ACKNOWLEDGEMENTS}

This research formed a part of project no. 39130010, supported by the National Science Foundation of China. We thank Dr Peter van Berkum for supplying us with the USDA isolates.

\section{NOTE ADDED IN PROOF}

While this manuscript was in preparation for publication, Young et al. (2001) proposed a revision of the genus Rhizobium, so that it would include all species of the genus Agrobacterium and Allorhizobium undicola. Fig. 2 has been changed to reflect the amended classification, as has the text of the manuscript. The almost-complete $16 \mathrm{~S}$ rRNA gene sequence of $B$. liaoningense was also deposited within GenBank during this time (Willems et al., 2001).

\section{REFERENCES}

Allen, O. N. \& Allen, E. K. (1981). The Leguminosae: A Source Book of Characteristics, Uses, and Nodulation. Madison, WI: University of Wisconsin.

Barrera, L. L., Trujillo, M. E., Goodfellow, M., García, F. J., Hernández-Lucas, I., Dávila, G., van Berkum, P. \& Martínez-Romero, E. (1997). Biodiversity of bradyrhizobia nodulating Lupinus spp. Int $J$ Syst Bacteriol 47, 1086-1091.

Campanacci, L., Romagnoli, G. F., Borsatti, A., Mendola, R., Maschio, G., Poli, D. \& Todesco, S. (1965). Effects of the purified fraction of 'Lespedeza capitata' on kidney function in the normal subject and in the kidney disease patient. Minerva Med 56, 4288-4298 (English translation).

Chen, W., Wang, E., Wang, S., Li, Y., Chen, X. \& Li, Y. (1995). Characteristics of Rhizobium tianshanense sp. nov., a moderately and slowly growing root nodule bacterium isolated from an arid saline environment in Xinjiang, People's Republic of China. Int $J$ Syst Bacteriol 45, 153-159.

Chen, W. X., Yan, G. H. \& Li, J. L. (1988). Numerical taxonomic study of fast-growing soybean rhizobia and a proposal that Rhizobium fredii be assigned to Sinorhizobium gen. nov. Int J Syst Bacteriol 38, 392-397.

Chen, W. X., Li, G. S., Qi, Y. L., Wang, E. T., Yuan, H. L. \& Li, J. L. (1991). Rhizobium huakuii sp. nov. isolated from the root nodules of Astragalus sinicus. Int J Syst Bacteriol 41, 275-280. 
de Lajudie, P., Willems, A., Pot, B. \& 7 other authors (1994). Polyphasic taxonomy of rhizobia: emendation of the genus Sinorhizobium and description of Sinorhizobium meliloti comb. nov., Sinorhizobium saheli sp. nov., and Sinorhizobium teranga sp. nov. Int J Syst Bacteriol 44, 715-733.

de Lajudie, P., Laurent-Fulele, E., Willems, A., Tork, U., Coopman, R., Collins, M. D., Kersters, K., Dreyfus, B. \& Gillis, M. (1998a). Allorhizobium undicola gen. nov., sp. nov., nitrogen-fixing bacteria that efficiently nodulate Neptunia natans in Senegal. Int J Syst Bacteriol $\mathbf{4 8 ,}$ 1277-1290.

de Lajudie, P., Willems, A., Nick, G. \& 9 other authors (1998b). Characterization of tropical tree rhizobia and description of Mesorhizobium plurifarium sp. nov. Int J Syst Bacteriol 48, 369-382.

De Ley, J. (1970). Reexamination of the association between melting point, buoyant density, and chemical base composition of deoxyribonucleic acid. $J$ Bacteriol 101, 738-754.

De Ley, J., Cattoir, H. \& Reynaerts, A. (1970). The quantitative measurement of DNA hybridization from renaturation rates. Eur $J$ Biochem 12, 133-142.

Dupuy, N., Willems, A., Pot, B. \& 7 other authors (1994). Phenotypic and genotypic characterization of bradyrhizobia nodulating the leguminous tree Acacia albida. Int $J$ Syst Bacteriol 44, 461-473.

Eckhardt, T. (1978). A rapid method for the identification of plasmid deoxyribonucleic acid in bacteria. Plasmid 1, 584-588.

Gamble, G. R., Akin, D. E., Makkar, H. P. S. \& Becker, K. (1996). Biological degradation of tannins in sericea lespedeza (Lespedeza cuneata) by the white rot fungi Ceriporiopsis subvermispora and Cyathus stercoreus analyzed by solid-state ${ }^{13} \mathrm{C}$ nuclear magnetic resonance spectroscopy. Appl Environ Microbiol 62, 3600-3604.

Gao, J. L., Sun, J. G., Li, Y., Wang, E. T. \& Chen, W. X. (1994). Numerical taxonomy and DNA relatedness of tropical rhizobia isolated from Hainan Province, China. Int J Syst Bacteriol 44, 151-158.

Genetics Computer Group (1995). Program Manual for the Wisconsin Package, Version 8. Genetics Computer Group, 575 Science Drive, Madison, WI, USA.

Graham, P. H., Sadowsky, M. J., Keyser, H. H. \& 8 other authors (1991). Proposed minimal standards for the description of new genera and species of root- and stem-nodulating bacteria. Int J Syst Bacteriol 41, 582-587.

He, S. Y. (1993). Beijing Flora, vol. 1. Beijing: Beijing Press (in Chinese).

Hynes, M. F. \& McGregor, N. F. (1990). Two plasmids other than the nodulation plasmid are necessary for formation of nitrogen-fixing nodules by Rhizobium leguminosarum. Mol Microbiol 4, 567-574.

Jarvis, B. D. W., van Berkum, P., Chen, W. X., Nour, S. M., Fernandez, M. P., Cleyet-Marel, J. C. \& Gillis, M. (1997). Transfer of Rhizobium loti, Rhizobium huakuii, Rhizobium ciceri, Rhizobium mediterraneum, and Rhizobium tianshanense to Mesorhizobium gen. nov. Int $J$ Syst Bacteriol 47, 895-898.

Jordan, D. C. (1982). Transfer of Rhizobium japonicum Buchanan 1980 to Bradyrhizobium gen. nov., a genus of slow-growing, root nodule bacteria from leguminous plants. Int J Syst Bacteriol 32, 136-139.

Jordan, D. C. (1984). Family III. Rhizobiaceae Conn 1938, 321 ${ }^{\mathrm{AL}}$. In Bergey's Manual of Systematic Bacteriology, vol. 1, pp. 234-254. Edited by N. R. Krieg \& J. G. Holt. Baltimore: Williams \& Wilkins.

Kuykendall, L. D., Saxena, B., Devine, T. E. \& Udell, S. E. (1992). Genetic diversity in Bradyrhizobium japonicum Jordan 1982 and a proposal for Bradyrhizobium elkanii sp. nov. Can J Microbiol 38, 501-505.

Ladha, J. K. \& So, R. B. (1994). Numerical taxonomy of photosynthetic rhizobia nodulating Aeschynomene species. Int $J$ Syst Bacteriol 44, $62-73$.

Lafay, B. \& Burdon, J. J. (1998). Molecular diversity of rhizobia occurring on native shrubby legumes in Southeastern Australia. Appl Environ Microbiol 64, 3989-3997.
Lindström, K. (1989). Rhizobium galegae, a new species of legume root nodule bacteria. Int J Syst Bacteriol 39, 365-367.

Marmur, J. (1961). A procedure for the isolation of DNA from microorganisms. J Mol Biol 3, 208-218.

Martínez-Romero, E., Segovia, L., Mercante, F. M., Franco, A. A., Graham, P. \& Pardo, M. A. (1991). Rhizobium tropici, a novel species nodulating Phaseolus vulgaris L. beans and Leucaena sp. trees. Int J Syst Bacteriol 41, 417-426.

Nour, S. M., Fernandez, M. P., Normand, P. \& Cleyet-Marel, J.-C. (1994). Rhizobium ciceri sp. nov., consisting of strains that nodulate chickpeas (Cicer arietinum L.). Int J Syst Bacteriol 44, 511-522.

Page, R. D. (1996). TREE VIEW: an application to display phylogenetic trees on personal computers. Comput Appl Biosci 12, 357-358.

Sambrook, J., Fritsch, E. F. \& Maniatis, T. (1989). Molecular Cloning : a Laboratory Manual, 2nd edn. Cold Spring Harbor, NY: Cold Spring Harbor Laboratory.

Scholla, M. H. \& Elkan, G. H. (1984). Rhizobium fredii sp. nov., a fastgrowing species that effectively nodulates soybeans. Int $J$ Syst Bacteriol 34, 484-486.

Segovia, L., Young, J. P. W. \& Martínez-Romero, E. (1993). Reclassification of American Rhizobium leguminosarum biovar phaseoli type I strains as Rhizobium etli sp. nov. Int J Syst Bacteriol 43, 374-377.

Sneath, P. H. A. \& Sokal, R. B. (1973). Numerical Taxonomy. The Principles and Practice of Numerical Classification. San Francisco: W. H. Freeman.

So, R. B., Ladha, J. K. \& Young, J.P. W. (1994). Photosynthetic symbionts of Aeschynomene spp. form a cluster with bradyrhizobia on the basis of fatty acid and rRNA analyses. Int J Syst Bacteriol 44, 392-403.

Tan, Z.-Y., Xu, X.-D., Wang, E.-T., Gao, J.-L., Martínez-Romero, E. \& Chen, W.-X. (1997). Phylogenetic and genetic relationships of Mesorhizobium tianshanense and related rhizobia. Int J Syst Bacteriol 47, 874-879.

Tan, Z. Y., Wang, E. T., Peng, G. X., Zhu, M. E., Martínez-Romero, E. \& Chen, W. X. (1999). Characterization of bacteria isolated from wild legumes in the north-western regions of China. Int J Syst Bacteriol 49, 1457-1469

Thompson, J. D., Higgins, D. G. \& Gibson, T. J. (1994). CLUSTAL W: improving the sensitivity of progressive multiple sequence alignment through sequence weighting, position-specific gap penalties and weight matrix choice. Nucleic Acids Res 22, 4673-4680.

van Berkum, P., Tully, R. E. \& Keister, D. L. (1995). Nonpigmented and bacteriochlorophyll-containing bradyrhizobia isolated from Aeschynomene indica. Appl Environ Microbiol 61, 623-629.

van Berkum, P., Beyene, D., Bao, G., Campbell, T. A. \& Eardly, B. D. (1998). Rhizobium mongolense sp. nov. is one of three rhizobial genotypes identified which nodulate and form nitrogen-fixing symbioses with Medicago ruthenica [(L.) Ledebour]. Int J Syst Bacteriol 48, 13-22.

van Rossum, D., Schuurmans, F. P., Gillis, M., Muyotcha, A., van Verseveld, H. W., Stouthamer, A. H. \& Boogerd, F. C. (1995). Genetic and phenetic analyses of Bradyrhizobium strains nodulating peanut (Arachis hypogaea L.) roots. Appl Environ Microbiol 61, 1599-1609.

Vincent, J. M. (1970). A Manual for the Practical Study of Root Nodule Bacteria. Oxford: Blackwell Scientific.

Wang, E. T., van Berkum, P., Sui, X. H., Beyene, D., Chen, W. X. \& Martínez-Romero, E. (1999). Diversity of rhizobia associated with Amorpha fruticosa isolated from Chinese soils and description of Mesorhizobium amorphae sp. nov. Int J Syst Bacteriol 49, 51-65.

Ward, D. M. (1998). A natural species concept for prokaryotes. Curr Opin Microbiol 1, 271-277.

Wayne, L. G., Brenner, D. J., Colwell, R. R. \& 9 other authors (1987). International Committee on Systematic Bacteriology. Report of the ad hoc committee on reconciliation of approaches to bacterial systematics. Int J Syst Bacteriol 37, 463-464. 
Weisburg, W. G., Barns, S. M., Pelletier, D. A. \& Lane, D. J. (1991). $16 \mathrm{~S}$ ribosomal DNA amplification for phylogenetic study. J Bacteriol 173, 697-703.

Willems, A. \& Collins, M. D. (1993). Phylogenetic analysis of rhizobia and agrobacteria based on 16S rRNA gene sequences. Int $J$ Syst Bacteriol 43, 305-313.

Willems, A., Coopman, R. \& Gillis, M. (2001). Phylogenetic and DNA-DNA hybridization analyses of Bradyrhizobium species. Int $J$ Syst Evol Microbiol 51, 111-117.

Xu, L. M., Ge, C., Cui, Z., Li, J. \& Fan, H. (1995). Bradyrhizobium liaoningense sp. nov., isolated from the root nodules of soybeans. Int $J$ Syst Bacteriol 45, 706-711.
Young, J. P. W. \& Haukka, K. E. (1996). Diversity and phylogeny of rhizobia. New Phytol 133, 87-94.

Young, J. P. W., Downer, H. L. \& Eardly, B. D. (1991). Phylogeny of the phototrophic Rhizobium strain BTAil by polymerase chain reaction-based sequencing of a $16 \mathrm{~S}$ rRNA gene segment. J Bacteriol 173, 2271-2277.

Young, J. M., Kuykendall, L. D., Martínez-Romero, E., Kerr, A. \& Sawada, H. (2001). A revision of Rhizobium Frank 1889, with an emended description of the genus, and the inclusion of all species of Agrobacterium Conn 1942 and Allorhizobium undicola de Lajudie et al. 1998 as new combinations: Rhizobium radiobacter, $R$. rhizogenes, $R$. rubi, R. undicola and R. vitis. Int J Syst Evol Microbiol 51, 89-103. 